\title{
Investigating the Effective Psychological and Economic Factors in Choosing Machine-woven Carpets from the Viewpoints of the Citizens of Ahwaz, Iran
}

\author{
Seyed Abdolghaffar Mousavi \\ Theran Javaher Carpet Iran, Thran, Theran \\ Mozhgan Akbari \\ Mandegar clinic Iran, Isfahan, Shahin Shahr \\ Sima Alizadeh \\ Faculty of Built Environment, University of New South Wales, \\ Sydney, NSW 2052, Australia \\ Minoo Sadeghi \\ Mandegar clinic, Iran, Isfahan, Shahin Shahr \\ Sara Mirshekari \\ Consultant, Iran, Isfahan, Isfahan
}

\begin{abstract}
Carpet is generally one of the basic necessities of Iranian families and from a long time ago the use of this product is considered as one of the requirements of Iranian life. According to this necessity, the purpose of this study is to investigate and identify the most effective economic and psychological factors in the choice of machine-woven carpet. The present study is an applied study with a descriptive-analytical approach. Its statistical population includes Ahwazi citizens of Iran visiting all the branches of Imam Reza Carpet Market during the winter of 2017 in order to select or buy carpets. From among these people, 270 were randomly selected and surveyed. The data gathering instrument was a researcher-made questionnaire. In order to analyze the data in this study, the exploratory factor analysis, confirmatory factor analysis, Pearson correlation coefficient., independent-samples t-test, one-way ANOVA test and Duncan's test were used. The results of this research indicated that regarding the viewpoints of Ahwazi citizens visiting Imam Reza Carpet Market, both economic and psychological factors were effective in choosing machine-woven carpets, however, the economic and pricerelated factors had the highest effect.
\end{abstract}

Key words: psychological factors, economic factors, machine-woven carpet, handmade costume of Iran

\section{INTRODUCTION}

Carpet is one of the oldest handmade costume of Iran, and one of the cultural and artistic attributes of Iranian ethnicities. Indeed, two thousand years of Iranian culture and civilization and all the technical achievements of Iranians in handicraft arts are reflected in carpet. Therefore, Persian carpet is not only important in terms of beauty and art, but also the source of livelihoods of a large group of people of the country (Farahbakhsh, 2002). 
The importance of carpet, both machine-woven and handmade in Iranian homes, has not been covered to anyone ever since. Iranian homes were thoroughly covered by carpet in the past (Daneshgar, 2009) and according to research conducted by domestic institutions, nowadays $90 \%$ of the population over 15 years old living in the big cities of the country use machinewoven carpets in their homes. This figure seems to be rising due to the more affordable price of machine-woven carpets than handmade carpets, their harmony with modern tastes and decoration, greater availability, more varied sizes and more softness (Mirza Amini \& Siddiqi Arfaei, 2011).

Considering the mentioned statistics, on the one hand, and the importance of preserving the Iranian culture and art and advertising it through the handmade and machine-woven carpets, on the other hand, this study intends to take an effective step in better delivering this product to customers through identifying the effective psychological and economic factors in choosing machine-woven carpet, as well as develop a new insight into the horizons of thought of the architects of this industry.

Through studying available scientific and research sources, as well as surveying some experts in this industry, it seems, that so far, no independent research has been performed to simultaneously considers a set of psychological and economic factors and in two distinct axes. Perhaps this neglect has been more felt especially in the context of the impact of various psychological factors on the choice of machine-woven carpets.

Regarding the importance and necessity of addressing this subject, it must be mentioned that being up-to-date and using the thoughts and tastes in machine-woven carpet industry, especially in its design, can play a valuable role as an important factor both in domestic production and in the export of this product, especially in order to get rid of oil-dependent economy (Jahangir, 2014; Rad, 2017).

It should also be acknowledged that conducting various researches in this field and applying the results can both expand this industry more as well as creating of more job opportunities. Conduction more relevant researches can also result in maintaining the strength of this product as a national brand and the cultural symbol of Iran.

\section{LITERATURE REVIEW}

By studying available sources, including valid articles and relevant books, some of the related axes to the subject can be found such as the one conducted by Mirza Amini and Sedighi Arfaei (2011). This study, which was carried out in several stages of surveying, showed that $63 \%$ of the surveyed people indicated that in the first stage, the price of machine-woven carpets was a determining factor in their choice. In this regard, Jahangir (2017) also stated that the inability of most Iranian families to buy handmade carpets is among the factors which makes customers more willing to buy machine-woven carpets.

The study of designing and constructing based on Iranian art and its impact on the development of the machine-based industry are other topics that have been considered. For instance, in an article entitled "Future Studies in the Carpet Machinery Industry", Iran Textile and Garment Production and Export Union highlighted the importance of the development of machine-woven carpet industry from Iranian art and taste point of view.

According to this article, " based on Iranian art and verve which have made the handmade carpets globally well-known over the years, as well as modern technologies, it is possible to 
make popular machine-woven carpets with beautiful designs that carry the spirit of Iranian art in them.

Moreover, despite proper background and acceptable technical knowledge of production, the carpet industry has lost its relatively respectable position internationally; which is due to occasional contradictions and mistakes as well as the lack of logical decision-making and moment-based thinking instead of foresight since the imposed war between Iran and Iraq (Iran Textile and Garment Production and Export Union, 2014).

Regarding the effect of carpet advertising, which is one of the components of this research, a study has been performed by Oliaei Tabaee, Shahparvari and Mirza Amini (2017). The results of this study, have shown that communication environmental stimuli have respectively the highest effect on the cognitive and emotional responses of users.

Furthermore, Sadeghi (2017) pointed out the importance of the role of colors and designs in the international competition. She believed that one of the reasons of success of Turkey's products is the variety of colors and designs, therefore as a developing country, Turkey has gained a position in Iran's market and also is conquering the international markets. She further declared that production costs in Iran are surely very high and creating a variety of designs and colors is something that does not happen without the support of the manufacturers. In this regard, Beheshti (2018) also emphasized the importance of creativity in designs and its role in the development of machine-woven carpet industry. He believed that if creativity and innovation in the designs are not valued and supported, everyone in the market looks for imitating and copying which, in turn, cause the failure of Iran's carpet industry against foreign manufacturers.

In addition to the above-mentioned studies, the role of access rate to the goods in the economic growth of the carpet industry has also been discussed by the experts. In this regard, Rouhani, Sadeghi, Golshani and Zabeti (2018) stressed the important and effective role of carpet hypermarkets. They pointed out to the following as the desirable outcomes of this process.

- Respecting and having appropriate interaction with customers

- Collecting all products and brands in one conveniently standard place

- Professionalization of salespeople and their functioning as customers' purchasing consultants

- Increasing customers' power of choice

\section{RESEARCH HYPOTHESES}

Hypothesis 1: There is a relationship between the economic factors and the choice of carpet from the viewpoints of Ahwazi citizens who visit Imam Reza Carpet Market in Ahwaz, Iran.

Hypothesis 2: There is a relationship between the psychological factors and the choice of carpet from the viewpoints of Ahwazi citizens who visit Imam Reza Carpet Market in Ahwaz, Iran.

\section{STATISTICAL POPULATION}

The statistical population of the present study consists of Ahwazi citizens of Iran who went to the branches of Imam Reza Carpet Market in order to buy carpets. From among them, 270 were randomly selected and surveyed. The Imam Reza Carpet Market has four branches in the city of Ahwaz, Iran which provide a variety of great machine-woven carpets and every day 
welcome hundreds of Ahwazi citizens from different parts of the city who visit these shops to select and buy carpets.

\section{RESEARCH METHOD AND DATA COLLECTION INSTRUMENTS}

The present study was an applied study with a descriptive-analytic approach in which the effect of some economic and psychological factors on carpet selection from the viewpoints of Ahwazi citizens visiting Imam Reza Carpet Market has been studied.

The data gathering instrument was a researcher-made questionnaire (appendix A) that was compiled from both research literature and interviewing several experts in this field and included 25 questions. The questionnaire responses range from one to five points in a form of Likert scale (from very high to very low). The questionnaire includes economic factors such as the quality of the goods, the price of the goods, and the role of provided facilities, as well as the psychological factors such as the designs and colors of the goods, the role of communication, the role of advertising, the role of arrangement and decoration of the shop and the role of product brand in the choice of machine-woven carpet. Furthermore, the questionnaire collected some demographic information including gender, age, and educational level of the customers.

The validity of this tool was reviewed and approved by theoretical study as well as using four experts' opinions on two axes of transparency and communication. Also, its reliability was calculated by Cronbach's test, which was equal to 0.87 (for 25 questions). And for internal consistency in each of the economic and psychological structures, the Cronbach alpha has been calculated separately (Table 1).

Table 1. Results of Cronbach's test in the evaluation of economic and psychological factors in choosing a carpet from an Ahwazi citizen's viewpoint visiting Imam Reza Carpet Market (2017)

\begin{tabular}{lllc}
\hline Factor & Sub-scale & \multicolumn{1}{c}{ Question } & Cronbach's alpha \\
\hline Economic & Quality & Questions 2, 3 and 5 & 0.517 \\
& Price & Questions 1,4 and 6 & 0.554 \\
& Facility & Questions 14, 18, 19 and 21 & 0.592 \\
\hline Psychological & Design and color & Questions 7, 8, 9, 10 and 11 & 0.695 \\
& Communication & Questions 15, 20 and 23 & 0.649 \\
& Advertising & Questions 13 and 22 & 0.598 \\
& Decoration & Questions 16 and 17 & 0.506 \\
& Being brand & Questions 24 and 25 & 0.593 \\
\hline
\end{tabular}

In this regard, at the descriptive level, for qualitative variables, absolute frequency and relative frequency percentage, and also for quantitative variables, mean and standard deviations were measured. Before exploring the hypotheses of the study at inferential level, exploratory factor analysis (EFA) was used to identify the indicators as well as the relationship among them. Then, by utilizing AMOS software and the confirmatory factor analysis (CFA), the regression weight (effect rate) of different structures was measured. Also, the correlation between the structures was investigated by using Pearson correlation coefficient. For comparing the mean of two and more than two independent groups, independent-samples t-tests and One-way ANOVA were respectively used. In this regard, Duncan test was also used as a follow-up test in order to compare the independent mean pair. The significance level of all tests was considered at the level of $5 \%$.

\section{FINDINGS}

Among the visitors of Imam Reza Carpet Market, 260 Ahwazi citizens were randomly selected and surveyed. However, 257 questionnaires were returned completed. The average age of the 
participants was 35 years old with a standard deviation of 10 years. Among them, 67.1\% were female with an average age of $34 \pm 10$ years (mean age \pm standard deviation). The mean age of the male group was $38 \pm 10$ years. Among the participants, 34.3\% had a diploma or lower degrees, $14.2 \%$ had an associated diploma and 51.5\% had bachelor's or higher degrees.

Before examining the research hypotheses, by using the Kaiser-Meyer-Olekin (KMO) and Croight Bartlett tests, the validity of the variables and the research factors were investigated. According to the results, the amount of extraction in one question (Question 12) was less than 0.05. Therefore, this question was omitted from the analysis of the questionnaire, and the value of KMO and Bartlett statistics analysis were calculated again. The value of the sample adequacy index was 0.818 and more than 0.5 . Accordingly, it can be concluded that the covariance between the proposed questions for measuring the main research structures was sufficient to extract at least one factor. On the other hand, the level of significance of the Bartlett test was less than $0.001(\mathrm{p}<0.001)$; this conclusion suggests that a proper sampling of the variables was performed and the pairwise correlation coefficients between questions and their partial correlation with zero were significantly different. In this study, confirmatory factor analysis (CFA) among 24 questions of the questionnaire was also applied. Table 2 indicates the summary of the results of exploratory factor analysis.

Table 2. A summary of the results of exploratory factor analysis (EFA) in the study of economic and psychological factors in choosing a carpet from an Ahwazi citizen's viewpoint visiting Imam Reza Carpet Market (2017)

\begin{tabular}{|c|c|c|c|c|c|}
\hline Factor & Factor load & Question & Factor & Factor load & Question \\
\hline \multirow{3}{*}{ Quality } & 0.461 & Question 2 & \multirow[t]{5}{*}{ Color \& design } & 0.594 & Question 7 \\
\hline & 0.347 & Question 3 & & 0.481 & Question 8 \\
\hline & 0.387 & Question 5 & & 0.399 & Question 9 \\
\hline \multirow[t]{3}{*}{ Price } & 0.482 & Question 1 & & 0.422 & Question 10 \\
\hline & 0.389 & Question 4 & & 0.436 & Question 11 \\
\hline & 0.622 & Question 6 & \multirow[t]{3}{*}{ Communication } & 0.486 & Question 15 \\
\hline \multirow[t]{4}{*}{ Facility } & 0.588 & Question 14 & & 0.633 & Question 20 \\
\hline & 0.517 & Question 18 & & 0.644 & Question 23 \\
\hline & 0.549 & Question 19 & \multirow[t]{2}{*}{ Advertising } & 0.513 & Question 13 \\
\hline & 0.474 & Question 21 & & 0.625 & Question 22 \\
\hline Being & 0.628 & Question 24 & \multirow[t]{2}{*}{ Decoration } & 0.385 & Question 16 \\
\hline brand & 0.552 & Question 25 & & 0.574 & Question 17 \\
\hline
\end{tabular}

The descriptive values of the economic and psychological factors in the choice of carpet and its sub-comparison in the designed questionnaire are presented in Table 3. The mean of the economic factor in choosing a carpet from the customers' viewpoint was $40.18 \pm 4.91$ and the mean of psychological score was $57.27 \pm 7.71$. 
Mousav, S. A., Akbari, M., Alizadeh, S., Sadeghi, M., \& Mirshekari, S. (2019). Investigating the Effective Psychological and Economic Factors in

Table 3. Descriptive values of economic and psychological factors and their sub-scales in selecting machine-woven carpets from the viewpoints of Ahwazi citizens visiting Imam Reza

Carpet Market, 2017 ( $\mathbf{n}=257)$

\begin{tabular}{llccccc}
\hline Factor & Sub-scale & Number & Minimum & Maximum & Mean & $\begin{array}{c}\text { Standard } \\
\text { deviation }\end{array}$ \\
\hline Economic & -- & 256 & 25 & 50 & 40.18 & 4.91 \\
\hline \multirow{2}{*}{ Economic } & Quality & 256 & 4 & 15 & 11.65 & 2.12 \\
Sub-scales & Price & 256 & 5 & 15 & 11.35 & 2.19 \\
& Facility & 256 & 5 & 20 & 17.18 & 2.78 \\
\hline Psychological & -- & 256 & 27 & 70 & 57.27 & 7.71 \\
\hline \multirow{2}{*}{ Psychological } & Color \& design & 256 & 7 & 25 & 19.73 & 3.4 \\
Sub-scale & Communication & 256 & 3 & 15 & 13.10 & 2.17 \\
& Advertising & 254 & 2 & 10 & 7.96 & 1.81 \\
& Decoration & 256 & 2 & 10 & 8.85 & 1.42 \\
& Being brand & 255 & 2 & 10 & 7.73 & 2
\end{tabular}

* Because some of the participants did not fully complete the questionnaire, the frequency (number) of some of the sub-comparisons is not 257.

In addition, in this study, a confirmatory factor analysis was also used to evaluate the model of measuring hidden variables (structures) on the economic and psychological factors in choosing a carpet. However, before that, the co-linear hypothesis was studied by means of Pearson correlation test. According to the results presented in Table 4 , at the level of $1 \%(p<0.01)$ in both economic and psychological factors, correlation matrix showed a positive and significant relationship between the variables. Among the economic factors, the highest correlation coefficient was related to the relationship between price and quality variables with the amount of 0.27 . In terms of the psychological factors, the linear relationship between decoration and communication variables was higher than that of other variables $(r=0.49$ and $p<0.00)$.

Table 4. Relationship between economic and psychological factors in choosing carpet from the viewpoints of Ahwazi citizens visiting Imam Reza Carpet Market (March 2017)

\begin{tabular}{llllllll}
\hline Factor & & Variable & $\mathbf{1}$ & $\mathbf{2}$ & $\mathbf{3}$ & $\mathbf{4}$ & $\mathbf{5}$ \\
\hline Economic & 1 & Quality & 1 & & & & \\
& 2 & Price & $0.27^{* * *}$ & 1 & & & \\
\hline Psychological & 3 & Facility & $0.16^{* *}$ & $0.22^{* * *}$ & 1 & & \\
& 1 & Color and design & 1 & & & & \\
& 2 & Communication & $0.23^{* * *}$ & 1 & & & \\
& 3 & Advertising & $0.32^{* * *}$ & $0.4^{* * *}$ & 1 & & \\
& 4 & Decoration & $0.26^{* * *}$ & $0.49^{* * *}$ & $0.33^{* * *}$ & 1 & \\
& 5 & Being brand & $0.41^{* * *}$ & $0.28^{* * *}$ & $0.47^{* * *}$ & $0.24^{* * *}$ & 1 \\
\hline
\end{tabular}

The values presented are Pearson correlation coefficients

*** Significant value ( $\mathrm{p}$-value) less than 0.001

** Significant value ( $\mathrm{p}$-value) less than 0.01

The results of calculating the fit indicators of the model by economic and psychological factors in choosing a carpet are summarized in Table 5. According to the results of this table, in the economic factor, the Chi-square value was significant and less than 2 degrees of freedom ( $p<$ 0.001 and CMIN / DF = 172.1). The values of CFI, IFI, and TLI were greater than 0.9. The root mean square error estimation was less than the acceptable value of $0.08($ RMSEA $=026)$, which means all were desirable values, and PGFI $=392.0$ was less than 0.5 . Also, in the psychological factor, the values listed were within the permissible range. Moreover, the PGFI value of 556.0 was more than 0.5. Therefore, the measurement models are acceptable with respect to the general fit indices and the experimental data of the research confirm and support the 
developed theoretical model. In other words, fit model into economic and psychological factors is established.

Table 5. Fit model indices in the study of the economic and psychological factors of carpet selection from the viewpoints of Ahwazi citizens visiting Imam Reza Carpet Market

(March 2017)

\begin{tabular}{lcccccc}
\hline \multicolumn{1}{c}{ Factor } & CMIN/DF & CFI & IFI & TLI & PGFI & RMSEA \\
\hline Economic & 1.172 & 0.978 & 0.981 & 0.956 & 0.392 & 0.026 \\
Psychological & 1.434 & 0.957 & 0.959 & 0.936 & 0.556 & 0.041 \\
\hline
\end{tabular}

The results of the confirmatory factor analysis technique (CFA) are presented in Table 6. The results of fit models in CFA analysis show that the regression weight of all variables in the prediction of questionnaire items had a meaningful difference with zero at the confidence level of 99\%, except price factor in economic factor. In other words, these indices indicate that the fit of the measured models was desirable; and the loading of each variable into the corresponding variable (hidden) was statistically validated.

Table 6. Results of confirmatory factor analysis (CFA) for economic and psychological factors in choosing carpet from the viewpoints of Ahwazi citizens visiting Imam Reza Carpet Market (March 2017)

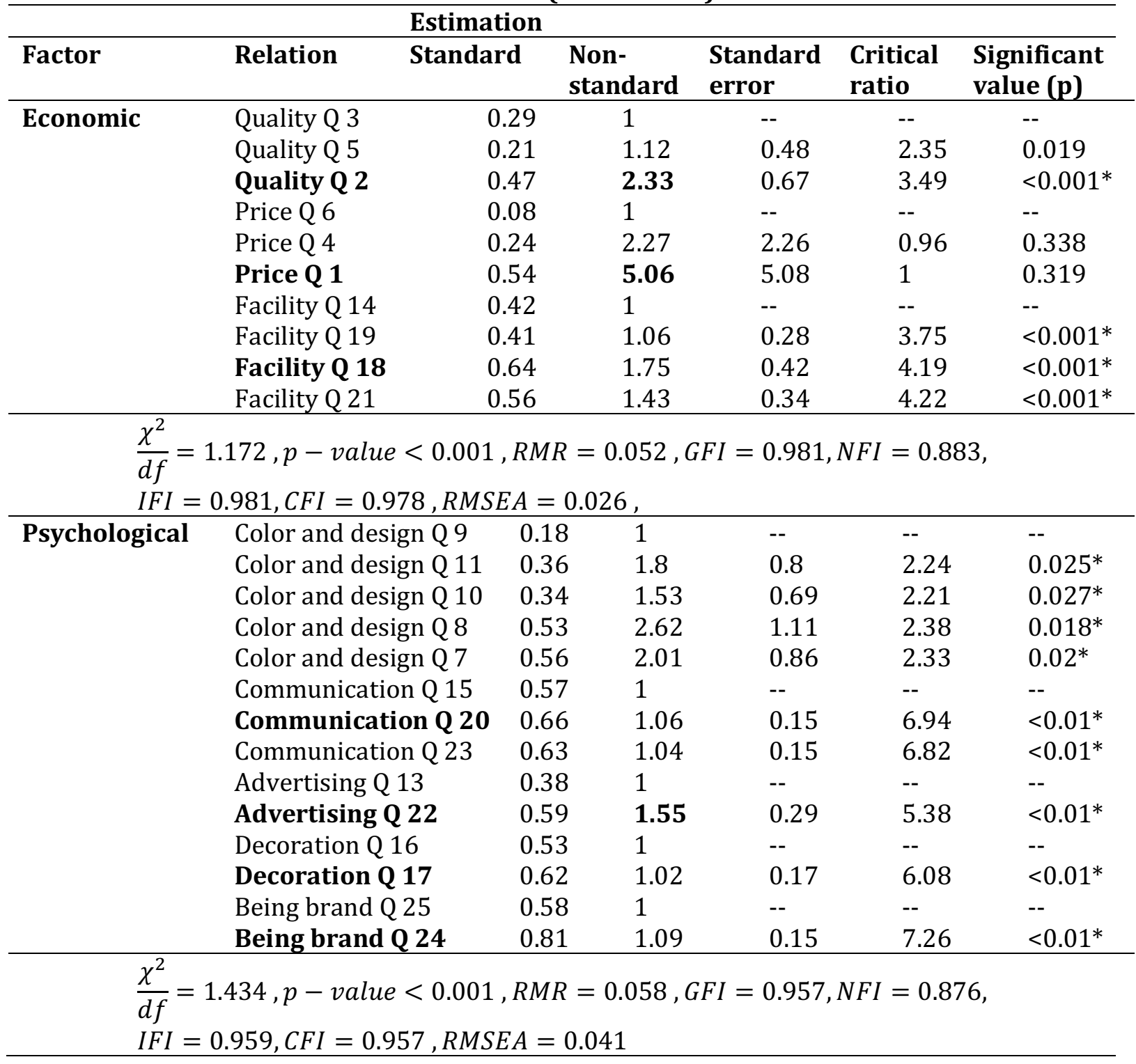


In the non-standard estimation column, variables that contain the value of one have been assumed as the reference variable in the measured model.

* Significance at the level of 5\%

Figures 1 and 2, respectively, show the measurement model of the research hidden variables by displaying the non-standardized regression weight (factor load) for the economic and psychological factors in choosing the carpet. In fact, these models show the intensity of the relationship between measured variables in the choice of carpet from the perspective of Ahwazi citizens in 2017.

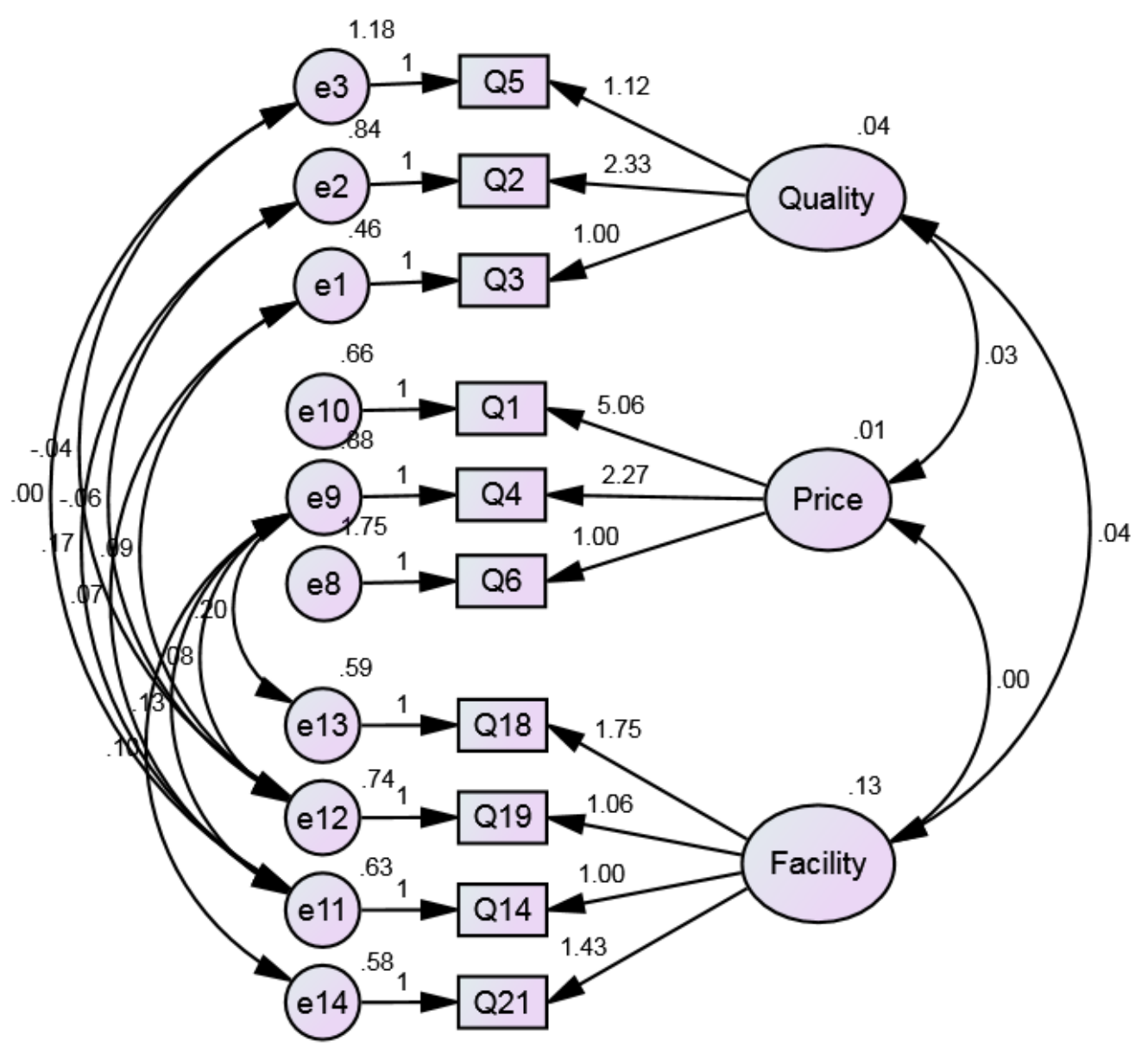

Figure 1. Confirmatory model of the economic factor in choosing a carpet by displaying nonstandardized factor loads 


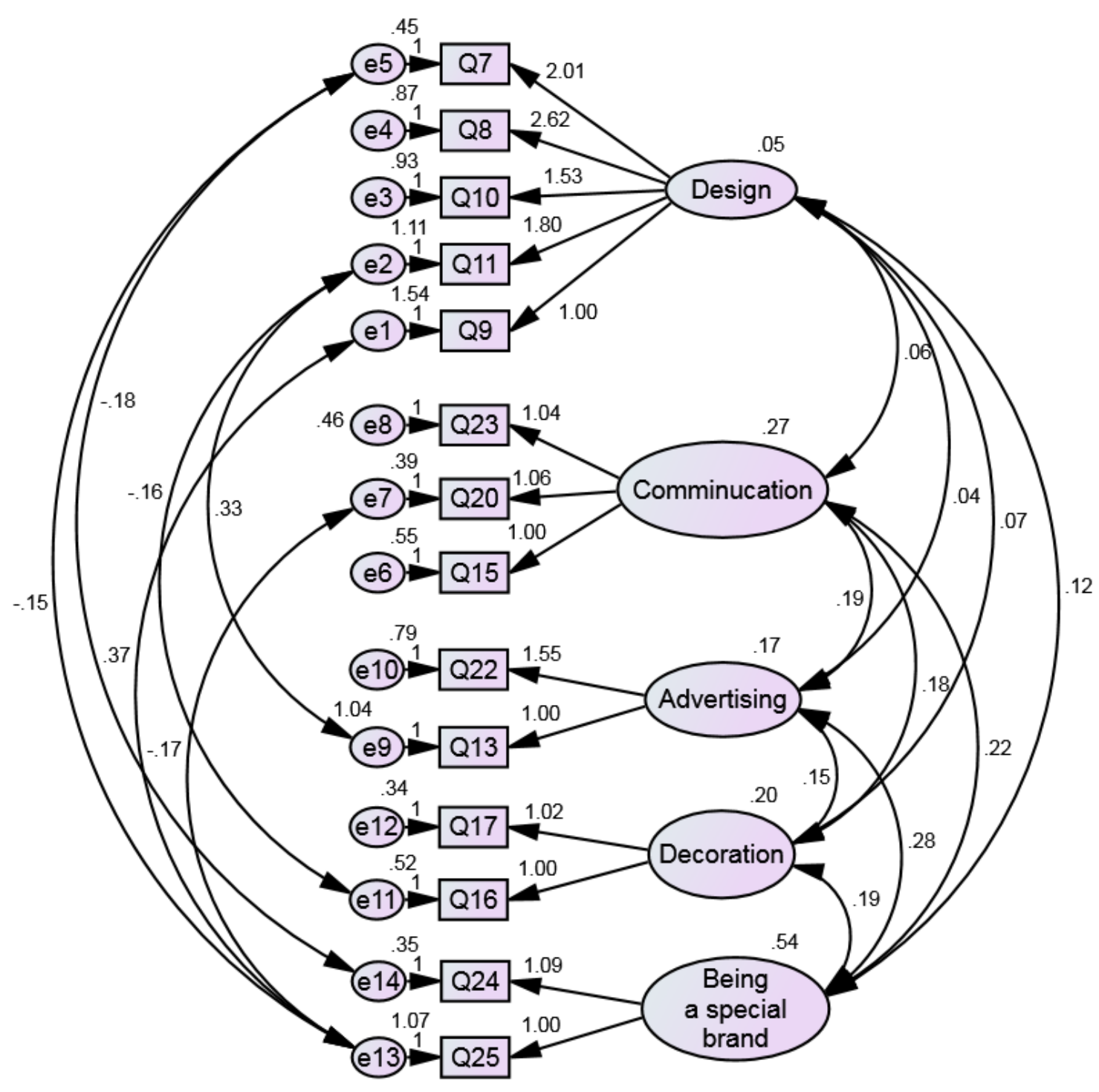

Figure 2. Confirmatory model of the psychological factor in choosing a carpet by displaying nonstandardized factor loads

According to the results of confirmatory factor analysis of the measured model, among the hidden variables of the economic factor, the sub-scale of quality (question 2 of the research questionnaire: (the priority of choosing a machine-woven carpet over a handmade carpet), the sub-scale of price (question 1 of the research questionnaire: (the price of machine-woven carpet in comparison with handmade carpet), and sub-scale of facility (question 18 of the research questionnaire: (selling conditions in installments) had the largest regression weights.

In other words, from the viewpoints of Ahwazi citizens visiting Tehran Jeweler Carpet Company, the mentioned questions had economically the most impact on their choice of carpet. In addition, as shown in Figure 2, from the viewpoints of the Ahwazi citizens, from the psychological factors, the sub-scale of designs and colors (question 8 of the research questionnaire: (traditional design inspired from handmade carpet designs), the communication sub-scale (question 20 of the research questionnaire: (the way of sellers' interaction with customers), the advertising sub-scale (question 22 of the research questionnaire: advertisement and introducing the product in different ways), the decoration sub-scale (question 17 of the research questionnaire: (an ideal shopping center), and the being 
brand sub-scale (question 24 of the research questionnaire: (special brand or different brand types) had the highest impacts on the choice of carpet.

\section{DISCUSSION AND CONCLUSION}

Carpet, in general, is one of the basic needs of Iranian families and this product has been used as one of the requirements of Iranian life from a long time ago. That is why it is of great importance to Iranian families. In this regard, the present research tried to examine two effective categories of psychological and economic factors in choosing a carpet (Figure 3), so that better and more effective improvements can be achieved in developing this industry.

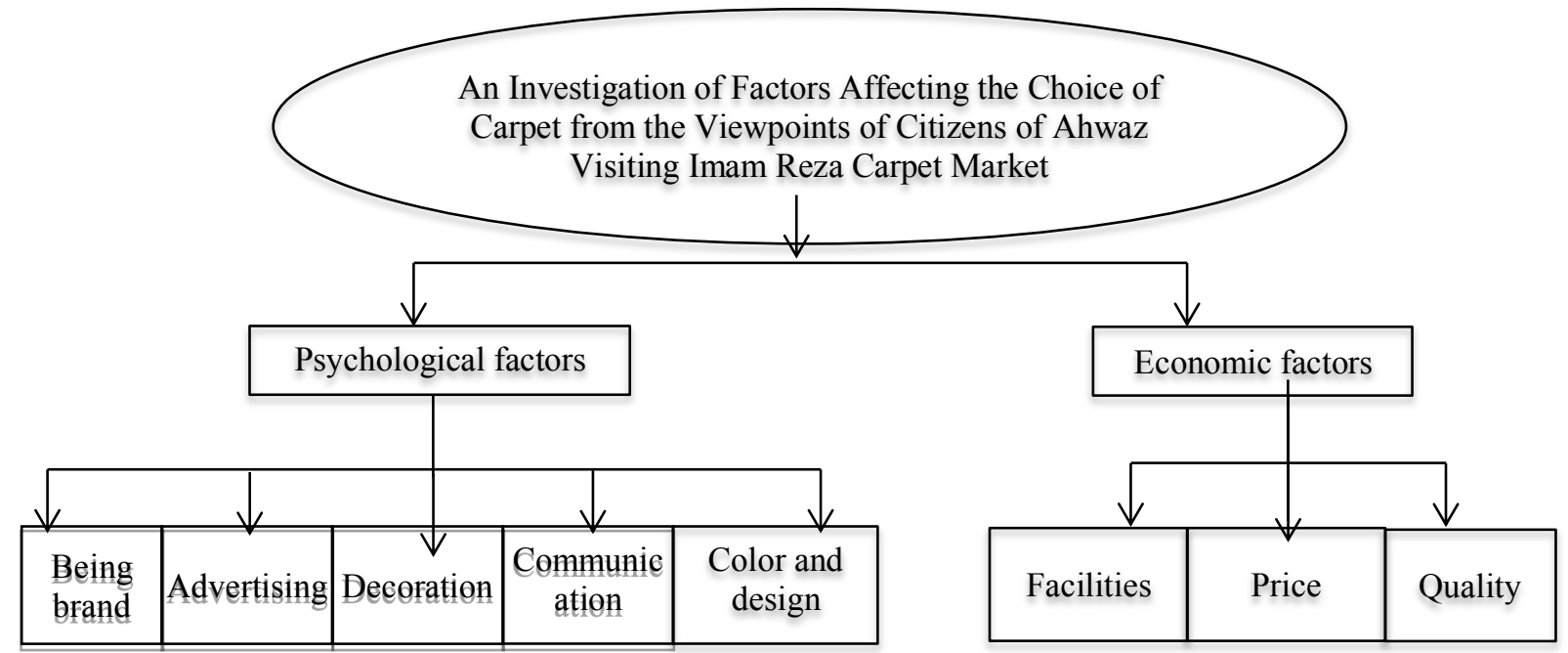

Figure 3. Factors influencing carpet selection from the viewpoints of Ahwazi citizens visiting Imam Reza carpet market

As it can be observed in Figure 3, in this research, economic factors including the product price (questions $1,4,6$ ), the product quality (questions $2,3,5$ ) and the facilities provided at the time of selling the product (questions 14,18,19, 21) have been studied. In this regard, after reviewing the results of customers' opinions visiting Imam Reza Carpet Markets in Ahwaz, it has been shown that among the price sub-factors, the priority of choosing machine-woven carpet over handmade carpet due to the price is the most important factor to the customers (Table 7).

Table 7. The results of the set of investigated factors related to the price of the product The set of investigated factors related to the price of Regression weight goods

\begin{tabular}{lc}
\hline $\begin{array}{l}\text { Question 1- The priority of choosing machine-woven } \\
\text { carpet over handmade carpet due to price }\end{array}$ & 5.06 \\
$\begin{array}{l}\text { Question 4- Price of goods } \\
\text { Question 6- Buying carpets at a reasonable price and } \\
\text { average quality }\end{array}$ & 2.27 \\
\end{tabular}

In explaining this factor, which was the most influential factor to the participants of the survey, it can be argued that machine-woven carpets are suitable for all segments of the population with different incomes. This is because the variety that exists in the market in terms of producing and supplying these carpets, enables almost all the customers to make a good purchase. On the other hand, the purchase of machine-woven carpets for the people who are willing to change their home decoration over and over, enables them to change their carpets along with other furniture like their sofa, at a more affordable price and through spending less expenses. 
The results of this study also indicated that although the price factor was the most significant factor in the tendency of customers towards the machine-woven carpets rather than handmade carpets, however, for the customers who went to Imam Reza Carpet Market solely to buy machine-woven carpets, price factor was in the fourth priority (Table 11). According to the research findings, this can be concluded that factors such as inspirational designs from handmade carpets and other features of machine-woven carpets are more important to the customers.

The results of the present study have also shown the impact of factors related to the quality of goods in the customers' selection (Table 8). However, it seems that the priority of choosing machine-woven carpet over handmade carpet is due to other features that are available along with the factor of appropriate price. Despite the quality of handmade carpets is higher than machine-woven carpets, it can be said that other features of machine-woven carpets, such as, customers' easy access and more choices, variety in designs and colors, fast production, being modern, and exact similarity of pairs of carpets are among the factors that explain the respondents' general tendency toward choosing the machine-woven carpets in comparison with handmade carpets.

Table 8. The results of the set of investigated factors related to the quality of goods The set of investigated factors related to the quality Regression weight of goods

Question 2- The priority of choosing machine-woven 2.33 carpet over handmade carpet Question 5- Buying carpets with high prices and excellent quality

Question 3- Quality of goods based on the consumed raw materials

In the rest of the discussion on the effect of other economic factors, the results showed that among the related factors to the facilities provided during the sale of goods, the conditions of selling goods in installments was the most effective factor (Table 9). In explaining the effect of this factor, it can be said that the terms of selling goods in the form of installments, on the one hand provides good conditions for sellers to have the opportunity of attracting more customers, and on the other hand customers, especially employees or other low-income groups of the society can sometimes buy their needed goods without any prepayment or paying just a small amount at first whenever they have the sellers' support. It should also be noted that this factor, besides being the most effective sub-factor among facilities factors, has also been as one of the most influential factors in the tendency of customers to choose and buy machine-woven carpets (Table 11).

Table 9. The results of the set of investigated factors related to the facilities provided when purchasing goods

\begin{tabular}{lc}
\hline $\begin{array}{l}\text { The set of investigated factors related to the facilities } \\
\text { provided when purchasing goods }\end{array}$ & Regression weight \\
\hline $\begin{array}{l}\text { Question 14- Services provided by the manufacturer at the time } \\
\text { pf purchase }\end{array}$ & 1 \\
$\begin{array}{l}\text { Question 18- Conditions of selling goods in the form of } \\
\text { installment }\end{array}$ & 1.75 \\
$\begin{array}{l}\text { Question 19- Services provided after the sale of carpets } \\
\text { Question 21- Considering special cases and incentives by the } \\
\text { manufacturer or retailers }\end{array}$ & 1.06 \\
\hline
\end{tabular}


As mentioned earlier, in addition to examining the impact of economic factors, the impact of psychological factors on the choice of machine-woven carpet has also been examined in this study. In this area, the first investigated factor was the effect of designs on the customers' selections. Based on the results of this survey, the priority of traditional designs with inspiration from handmade carpet designs has attracted a high percentage of responses (Tables 10). This factor was also the second most effective factor in the total set of investigated factors (Table 11).

Table 10. The results of the set of investigated factors related to the effect of design and color in choosing machine-woven carpets

\begin{tabular}{lc}
\hline $\begin{array}{l}\text { The set of investigated factors related to the impact of } \\
\text { design and color in choosing machine-woven carpets }\end{array}$ & Regression weight \\
\hline $\begin{array}{l}\text { Question 7- Variety in the design of machine-woven carpet } \\
\text { Question 8- Priority of traditional designs with respect to }\end{array}$ & 2.01 \\
inspiration from handmade carpet designs & 2.62 \\
$\begin{array}{l}\text { Question 9- Completely modern and non-traditional designs } \\
\text { Question 10 - Different color schemes and the use of countless }\end{array}$ & 1 \\
$\begin{array}{l}\text { colors } \\
\text { Question 11- Use of a limited and traditional color scheme so that } \\
\text { there is a color harmony across the entire carpet }\end{array}$ & 1.53 \\
\hline
\end{tabular}

In explaining this finding, it can be argued that the designs of the Iranian handmade carpets, which somehow contains the cultural, ethnic, and geographic variety of the country, are rooted in Iranian customs and culture and, in fact, most of the Iranian families have been adapted to it over time. These designs, in addition to being an artwork, seem to have different designs and types that each can be psychologically able to create a particular style and atmosphere at home. According to the results of this study, inspirational designs from handmade carpets, in addition to the artistic aspect, also retain the characteristic of popularity.

To confirm this statement, the respondents' answer to the question number 11 in the questionnaire can be considered. The question is: "How much using traditional and limited color schemes so that the color harmony can be visible across the entire carpet would affect your selection?" Regression weight assigned to this question has shown that the use of limited and traditional color schemes was the sixth most effective factor on the customers' selections. In this regard, the analysis of the respondents' answers to question 9, related to the impact of completely modern and non-traditional designs on the choice of carpets, shows that this factor has not had a significant impact on their selection, while the designs that inspired from the traditional carpets had the highest effect.

In the following, the research findings regarding the effect of interaction as one of the subscales of psychological factor is discussed. Acknowledging that based on the available sources of the related studies about the techniques for increasing sales and attracting customers, the effect of the way of seller or sellers' interaction with customers has been mentioned as an important factor. Nevertheless, this factor ranked in the 13th priority from among a total of 24 factors by customers of the Imam Reza Carpet Market. This conclusion suggests that, in choosing of machine-woven carpets, despite the fact that the influence of this factor cannot be ignored, however, from the viewpoints of customers who want to buy carpets, its impact was not among the first effective priorities (Table 12).

Furthermore, concerning the research psychological factors, the effects of the product arrangement as well as the style of decoration in the sales centers on the choice of customers of machine-woven carpets were investigated. The results indicate that from the viewpoints of 
the customers of Imam Reza Carpet Market, although the style of decoration and product management were influential, but their effectiveness were at the fifteenth place from among a total of 24 investigated factors.

Regarding the effect of this factor, it can be stated that the scope and depth of services provided in a commercial complex are in fact an answer to the expectations of the consumers of the product. The more these services are appropriate to the needs and expectations of the customers, the more effective factor it can also be in achieving the most efficiency. According to the conducted studies, factors such as internal designing and product arrangement with easy accessibility, easy access to shopping centers, variety in the provided products, proper lighting, parking, infrastructure area, and providing a pleasant shopping are among the factors that can be effective in attracting customers. However, in comparison with the other investigated factors for choosing machine-woven carpets, this effectiveness has not had a very crucial role.

The role of advertising factor is among the other psychological components discussed in this study. The role of this factor, in the various forms of media, and especially in the current era is undeniable. However, in this study, advertising was the eighth effective factor in attracting customers to purchase machine-woven carpets. For explaining this finding, it can be stated that the introduction of the product through the technology of communication and media has a significant impact on raising the level of awareness of customers about the product. Moreover, advertising makes customers informed about the innovations of the relevant company or companies.

In this regard, communication, expressing opinions and, in other words, orienting people thoughts about a particular brand in the form of interpersonal recommendations, are among the other psychological factors discussed in this research, which have been studied under the brand factor. According to the results of the current research, the impact of previous buyers' recommendations to other customers about a particular brand, which can also be considered as an advertising factor, was not a very effective factor in choosing carpet by the customers, and it is placed at the 12th priority from their viewpoints (Table 11). 
Table 11. The effective economic and psychological factors in choosing a carpet from the viewpoints of Ahwazi citizens visiting Imam Reza carpet market (prioritized from the most effective to the least effective factors)

\begin{tabular}{|c|c|c|c|}
\hline Row & Description of factors & The relevant field & Regression weight \\
\hline 1 & $\begin{array}{l}\text { Prioritizing machine-woven carpets over } \\
\text { handmade carpets due to price }\end{array}$ & Price-Economic & 5.06 \\
\hline 2 & $\begin{array}{l}\text { Prioritizing traditional designs with respect to } \\
\text { inspiration from handmade carpet designs }\end{array}$ & $\begin{array}{l}\text { Color and design - } \\
\text { Psychological }\end{array}$ & 2.62 \\
\hline 3 & $\begin{array}{l}\text { Prioritizing machine-woven carpets over } \\
\text { handmade carpets }\end{array}$ & Quality-Economic & 2.33 \\
\hline 4 & Price of goods & Price-Economic & 2.27 \\
\hline 5 & Variation in carpet designs & $\begin{array}{l}\text { Color and design - } \\
\text { Psychological }\end{array}$ & 2.01 \\
\hline 6 & $\begin{array}{l}\text { Using limited and traditional color scheme to } \\
\text { create color harmony in the entire carpet }\end{array}$ & $\begin{array}{l}\text { Color and design - } \\
\text { Psychological }\end{array}$ & 1.8 \\
\hline 7 & Conditions of sale in installment form & Facilities- Economic & 1.75 \\
\hline 8 & $\begin{array}{l}\text { Advertising and introducing products in } \\
\text { different ways }\end{array}$ & $\begin{array}{l}\text { Advertising - } \\
\text { Psychological }\end{array}$ & 1.55 \\
\hline 9 & $\begin{array}{l}\text { Different color schemes and the use of } \\
\text { countless colors }\end{array}$ & $\begin{array}{l}\text { Color and design - } \\
\text { Psychological }\end{array}$ & 1.53 \\
\hline 10 & $\begin{array}{l}\text { Applying special cases and incentives by the } \\
\text { manufacturers (e.g. awards, discounts, carpet } \\
\text { festivals, etc.) }\end{array}$ & Facilities- Economic & 1.43 \\
\hline 11 & $\begin{array}{l}\text { Buying carpets with high price and excellent } \\
\text { quality }\end{array}$ & Quality-Economic & 1.12 \\
\hline 12 & $\begin{array}{l}\text { Advice from previous buyers about a } \\
\text { particular brand }\end{array}$ & $\begin{array}{l}\text { Being brand - } \\
\text { Psychological }\end{array}$ & 1.09 \\
\hline \multirow[t]{2}{*}{13} & $\begin{array}{l}\text { Services provided after the sale of carpets (e.g. } \\
\text { guarantees, warranties, etc.) }\end{array}$ & Facilities- Economic & 1.06 \\
\hline & $\begin{array}{l}\text { Effective way of interaction by seller or sellers } \\
\text { with customers }\end{array}$ & $\begin{array}{l}\text { Communication - } \\
\text { Psychological }\end{array}$ & 1.06 \\
\hline 14 & $\begin{array}{l}\text { Professional responding to the customers in } \\
\text { terms of product specifications }\end{array}$ & $\begin{array}{l}\text { Communication - } \\
\text { Psychological }\end{array}$ & 1.04 \\
\hline 15 & Desirability of shopping center & $\begin{array}{l}\text { Decoration - } \\
\text { Psychological }\end{array}$ & 1.02 \\
\hline \multirow{8}{*}{16} & $\begin{array}{l}\text { Completely modern and non-traditional } \\
\text { designs }\end{array}$ & $\begin{array}{l}\text { Color and design - } \\
\text { Psychological }\end{array}$ & 1 \\
\hline & Easy access to carpet shopping centers & $\begin{array}{l}\text { Communication - } \\
\text { Psychological }\end{array}$ & 1 \\
\hline & $\begin{array}{l}\text { The possibility of visiting the carpet } \\
\text { production process }\end{array}$ & $\begin{array}{l}\text { Advertising - } \\
\text { Psychological }\end{array}$ & 1 \\
\hline & $\begin{array}{l}\text { Arrangement of products in a way that the } \\
\text { customers can choose by themselves }\end{array}$ & $\begin{array}{l}\text { Decoration - } \\
\text { Psychological }\end{array}$ & 1 \\
\hline & The sense of belonging to a particular brand & $\begin{array}{l}\text { Being brand - } \\
\text { Psychological }\end{array}$ & 1 \\
\hline & $\begin{array}{l}\text { Services provided by the manufacturer at the } \\
\text { time of purchase }\end{array}$ & Facilities -Economic & 1 \\
\hline & $\begin{array}{l}\text { To buy carpets at affordable prices and } \\
\text { average quality }\end{array}$ & Price -Economic & 1 \\
\hline & $\begin{array}{l}\text { Quality of goods based on the consumed raw } \\
\text { materials }\end{array}$ & Quality-Economic & 1 \\
\hline
\end{tabular}

Based on table 11, it can be generally concluded that from the viewpoints of Ahwazi citizens visiting Imam Reza Carpet Market, both economic factors and psychological factors are 
effective in choosing machine-woven carpets; however economic factors, especially the pricerelated ones are revealed to be the most influential factors. It can also be deduced from a more precise comparison that all the economic factors, including the price of goods, the quality of goods, and the role of the offered facilities in the selection of machine-woven carpets are very effective. And from among all psychological factors, the factors of designs and colors as well as advertising are shown to be more effective despite the fact that the effects of other factors cannot be denied.

It must be noted that implementing this study in Ahwaz city and only by the customers of Imam Reza Carpet Markets have been the limitations of this study. Therefore, it is suggested that similar research be carried out in other cities of Iran. Hereby, the owners of machinewoven carpet industry have a broader and more insightful view of the customers' tastes and expectations and can make more effective efforts to increase the quality of their products and the satisfaction of their customers.

\section{ACKNOWLEDGEMENTS}

We would like to thank Ms. Sepideh Abdollahi, an expert in the field of carpet, for her tremendous efforts as well as the personnel in Imam Reza Carpet Market who had fully been involved in the implementation of this study.

\section{References}

Beheshti, M. (2018). Science, Innovation and Creativity in Iran's Machine-woven Carpet Industry. Fars News Agency. News No. 13960622000025. Available at: www.farsnews.com

Daneshgar, A. (2009). Iranian Carpet Encyclopedia, Vol. II. Tehran: National Carpet Center of Iran.

Farahbakhsh, N. (2002). Investigating Effective Factors on Carpet Export. Economic Research. 223-235.

Haeri, A. (2015). Machine-woven Carpet: Pioneer of Textile Industry. Journal of the Industry, Mine and Trade Experties. 456(39). News No. 18734

Heshmati Razavi, F. (1999). Carpet History: Direction of the Evolution of Weaving Carpet in Iran. Tehran: Samt Publication.

Iran Textile and Garment Production and Export Union (2014). Future Studies of Iran's Machine-woven Carpet Industry. Available at: www.tccim.ir

Jahangir, A. (2016). Top Rank of Machine-woven Carpets Production Belongs to Iran. Presented at the 4th Iranian Machine-woven Carpets industry Conference. Gostaresh Tejarat Newspaper, 114(9).

Kamalian, M. (2015). Machine-woven Carpet: Pioneer of Textile Industry. Journal of the Industry, Mine and Trade Experties. 456(39). News No. 18734

Kargar, H. (2018). What is the Symbol of Iran? National Carpet Center of Iran. Available at: www.incc.com

Mirza Amini, M. \& Sedighi Arfaee, F. (2011). Factors Affecting the Sale of Handmade and Machine-woven Carpets in the Market of Iran. Goljam, Iranian Quarterly Journal of Scientific Carpet Association, 20, 21-39.

Moein, M. (1999). Moein Persian Dictionary. Tehran: Arad Publishing.

Mohajer Shojaee, K. (2017). Science, Innovation and Creativity in Iran's Machine-woven Carpet Industry. Fars News Agency. News No. 13960622000025. Available at: www.farsnews.com

Oliaei Tabaee, S. A., Shahparvari, M. R., \& Mirza Amini, S. M. (2017). Assessing the Effect of Internet Carpet Advertising with Emphasis on Consumers' Behavior. Goljam, Iranian Quarterly Journal of Scientific Carpet Association, 31, 1-17.

Rad, H. (2018). The Impact of Belgian Carpet to the Handmade and Machine-woven Carpet Market. Fars News Agency. Available at: www.farsnews.com

Rouhani, M., Sadeghi, M., Golshani, A \& Zabeti, M. (2018). Science, Innovation and Creativity in Iran's Machinewoven Carpet Industry. Fars news Agency. News No. 4084193. Available at: www.mehrnews.com

Sadeghi, M. (2017). Science, Innovation and Creativity in Iran's Machine-woven Carpet Industry. Fars News Agency. News No. 13960622000025. Available at: www.farsnews.com 
Zakipour, M. (2016). The World of Machine-woven Carpet in Post-sanctions Era. Available at:

www.cohanjournal.com

\title{
APPENDICES \\ Appendix A (the research questionnaire)
}

\author{
In the name of God
}

Dear customers, kindly be informed that:

In order to improve its qualitative and quantitative products, Tehran Jewelry Carpet intends to carry out a study under the title of "Investigating the Effective Psychological and Economic Factors in Choosing Machine-Woven Carpets from the Viewpoints of the Citizens of Ahwaz". Therefore, for this purpose, you are kindly requested to read the following questions carefully and mark your choices.

Thanks

\begin{tabular}{|c|c|c|c|c|c|c|}
\hline \multirow[t]{2}{*}{ Row } & \multirow[t]{2}{*}{ Questions } & $\begin{array}{l}\text { Very } \\
\text { High }\end{array}$ & High & $\begin{array}{c}\text { Fairly } \\
\text { High }\end{array}$ & Low & $\begin{array}{l}\text { Very } \\
\text { Low }\end{array}$ \\
\hline & & 1 & 2 & 3 & 4 & 5 \\
\hline 1 & $\begin{array}{l}\text { To what extent the priority of choosing handmade } \\
\text { carpet over machine-woven carpet due to price } \\
\text { factor is effective in your purchase? }\end{array}$ & & & & & \\
\hline 2 & $\begin{array}{l}\text { To what extent the priority of choosing handmade } \\
\text { carpet over machine-woven carpet is effective in } \\
\text { your purchase? }\end{array}$ & & & & & \\
\hline 3 & $\begin{array}{l}\text { To what extent is the quality of the goods based on } \\
\text { the consumed raw materials prioritized for you? }\end{array}$ & & & & & \\
\hline 4 & How important is the price of goods to your choice? & & & & & \\
\hline 5 & $\begin{array}{l}\text { How much do you prefer to buy a carpet with high } \\
\text { price and high quality? }\end{array}$ & & & & & \\
\hline 6 & $\begin{array}{l}\text { How much do you prefer to buy a carpet with } \\
\text { appropriate price and average quality? }\end{array}$ & & & & & \\
\hline 7 & $\begin{array}{l}\text { How much the variety in carpet designs is effective } \\
\text { in your choice? }\end{array}$ & & & & & \\
\hline 8 & $\begin{array}{l}\text { Does the priority of putting traditional designs } \\
\text { inspired from handmade carpet designs have a } \\
\text { good impact on you in making a better choice? }\end{array}$ & & & & & \\
\hline 9 & $\begin{array}{l}\text { How does the impact of completely modern and } \\
\text { non-tradition designs affect your carpet selection? }\end{array}$ & & & & & \\
\hline 10 & $\begin{array}{l}\text { How much do variety of color scheme and using } \\
\text { countless colors affect your carpet selection } \\
\text { process? }\end{array}$ & & & & & \\
\hline 11 & $\begin{array}{l}\text { How much using traditional and limited color } \\
\text { schemes so that the color harmony can be visible } \\
\text { across the entire carpet would affect your } \\
\text { selection? }\end{array}$ & & & & & \\
\hline 12 & $\begin{array}{l}\text { Do you prefer to buy carpet directly from the } \\
\text { factory or through the intermediaries? }\end{array}$ & & & & & \\
\hline 13 & $\begin{array}{l}\text { How much visiting a carpet manufacturing process, } \\
\text { if possible, would affect your choice? }\end{array}$ & & & & & \\
\hline 14 & $\begin{array}{l}\text { To what extent services provided by the } \\
\text { manufacturer at the time of buying affects your } \\
\text { purchase? }\end{array}$ & & & & & \\
\hline 15 & $\begin{array}{l}\text { To what extent does easy access to carpet shopping } \\
\text { centers affect your purchase? }\end{array}$ & & & & & \\
\hline 16 & $\begin{array}{l}\text { How the arrangement of products in the way that } \\
\text { customers can choose by themselves can be }\end{array}$ & & & & & \\
\hline
\end{tabular}




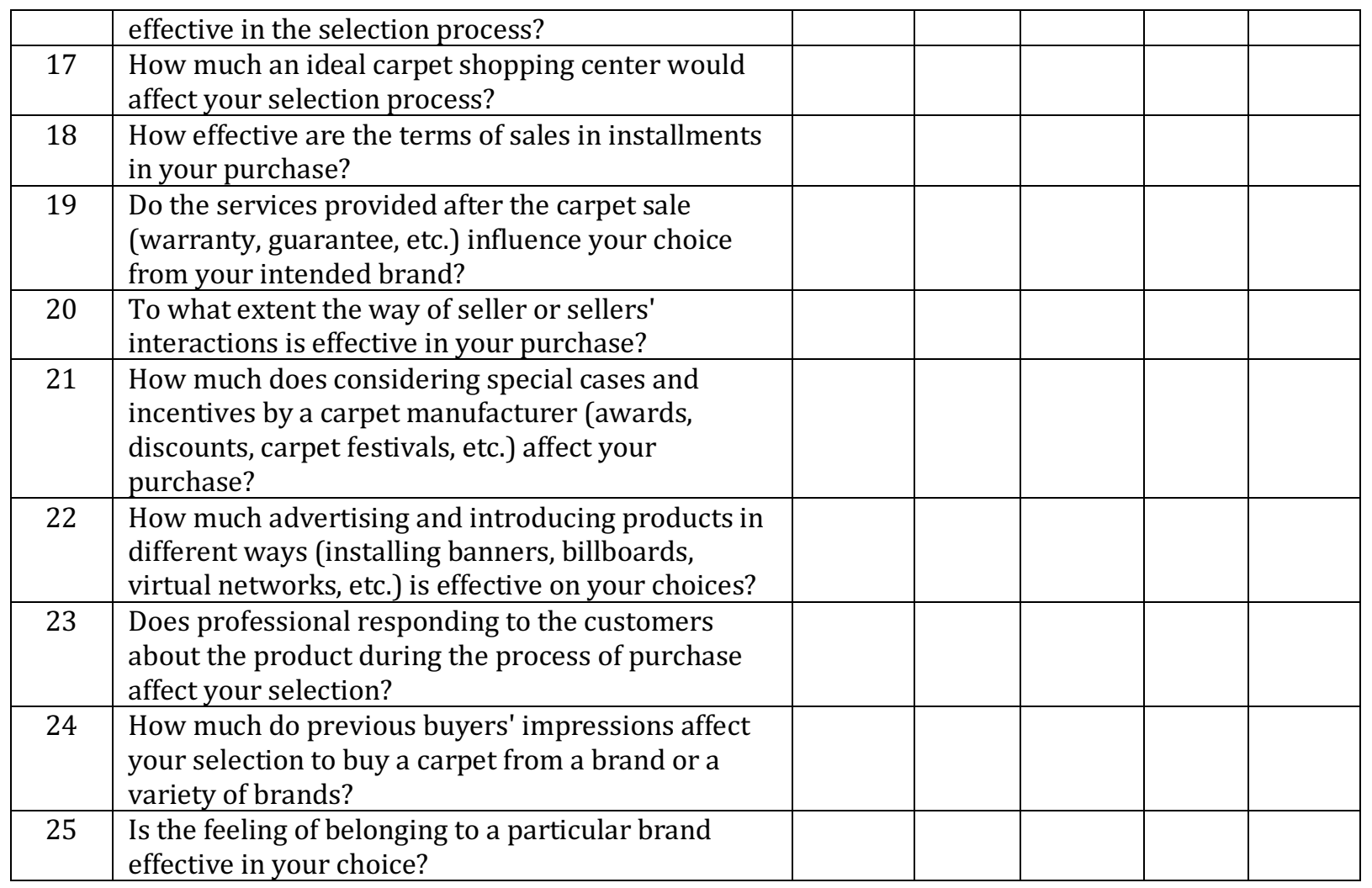

